\title{
Applied Financial Talents Cultivation Research for Universities under Financial Technology Background
}

\author{
Yunqiu Jiao ${ }^{1,}$, Peng Liu ${ }^{1, b}$ \\ ${ }^{1}$ Department of Economy and Management, Weifang University, Weifang, China, 261061 \\ awfjyqd@163.com, b'wflp888@163.com
}

Keywords: Finance technology, Finance, Talents training

\begin{abstract}
With the rapid development of financial science and technology, the financial industry has put forward new requirements for the training of financial talents in new era, and the new standard has also changed the employment demand in financial industry. It is worth exploring how to change the traditional educating and teaching methods according to the new talent market need, which is especially important to local universities aimed at the cultivation of applied talents.
\end{abstract}

\section{Introduction}

With the rapid development of financial technology represented by Internet, big data, cloud computing, artificial intelligence and block-chain, the financial industry has put forward new requirements and new standards for the training of financial professionals in the new era. Local colleges and universities should accurately grasp the new trends, new changes, change from passive to active, continue to explore new modes of personnel training, deepen education and teaching reform, improve the quality of personnel training.

\section{Impact of financial technology on financial sectors’ employment needs}

Emerging technologies such as artificial intelligence, big data, cloud computing and block-chain have posed new challenges to the business models, products, processes and application systems in the financial industry. Financial institutions must grasp the trend of the times, combine financial science and technology with all aspects of bank management and operation, take Internet thinking and actively apply advanced science and technology and business philosophy in all aspects of strategy, management, process, product, risk control, operation and service Carry out innovation and innovation, help science and technology to successfully transform and upgrade and realize its own development. In the process of transformation and upgrading, the demand for talents by the financial industry is also getting higher and higher, and great changes have taken place in the demand of employers.

Staff jobs needed in financial industry have significantly reduced. First of all, artificial intelligence in the algorithm of a huge breakthrough, making complex tasks greatly improve the accuracy of processing. Big data, artificial intelligence and block-chain will replace much of the financial industry's ability to collect analytic processing jobs and risk pricing. Pure information analysis and processing jobs will be replaced by artificial intelligence; Second, the rapid development of speech recognition technology, computer vision, etc., making it more advantageous to manage customer touch points through machines. Demand for personnel such as smart customer service, investment advisors, credit ratings and credit risk analysis positions will also be significantly reduced.

Types of talents needed in financial industry have been changed. Financial science and technology make new changes in the employment standards of the financial industry, requiring not only proficiency in financial theory and practice of financial professional knowledge, but also understand the big data, artificial intelligence, cloud computing and block-chain and other new technologies, and applied to work, But also have the psychological analysis, communication, strategic analysis and judgment, artificial intelligence cannot do the work. The original banks and other financial institutions need to recruit a large number of financial graduates each year, and now the "professional counterparts" to relax a lot of requirements, but more computer, math, psychology, professional 
background. Financial institutions have begun to no longer need pure macro financial management personnel, but need a large number of complex financial professionals.

\section{Existing problems of financial talents training in local universities}

The changes in the employment needs of the financial industry are facing great challenges to the training of financial professionals in local colleges and universities. However, local colleges and universities themselves still have many problems in financial professionals training, mainly in the following aspects:

Ambiguous talents training goals and inaccurate professional positioning. Although the training objectives of financial major in local colleges and universities clearly emphasize that the goal of personnel training is to cultivate applied talents, the specific solutions to the training programs usually use vague language, most of which use "to promote students' moral, physical, and comprehensive development" and " Theoretical knowledge, innovative ability and practical talents "and other words, rarely with the school's own school level, characteristics and teachers and other specific circumstances to set, and ultimately lead to the lack of a clear training objectives and professional positioning.

Unreasonable setting curriculum and obsolete teaching contents. In accordance with the requirements of the direction of application-oriented personnel training, local colleges and universities should set financial courses market-oriented, should have its own characteristics. However, due to the fact that education and teaching are out of touch with each other and teachers are scarce, many courses in macro finance such as finance, finance, central banking and investment studies have been opened up relatively. However, Internet finance, quantitative investment, Derivatives and other micro-finance courses and some courses and other subjects integration, such as computer programming, psychology, marketing and other open less, nor pay attention to the curriculum is extremely unreasonable, the teaching content is more obsolete, and the industry The difference between requirements is larger.

Single practicing style and poor actual effects. At present, most local colleges and universities have some problems in practice teaching, such as insufficient investment, restricted space, equipment shortage or obsolescence, shortages of professional teachers and so on. The experimental and training conditions of finance major cannot meet the requirements of practical teaching, resulting in the practical teaching Single, slow content updates, and business needs do not match. The organization of students to business internship links, but also mostly stay in the visit and other cognitive internships, students rarely have the opportunity to participate and hands-on teaching, the actual teaching results are not good.

Lack of a high quality teaching staffs with comprehensive abilities. The financial strength of teachers in local colleges and universities is relatively weak. According to the disposition of teachers, one is that there are fewer full-time teachers in the financial field and fewer financial professors with disciplines such as computers. The second is that most teachers lack financial professions or enterprises work experience. Third, due to the lack of corresponding supporting measures, the enthusiasm of teachers to attachments to financial institutions or to train for further studies is not high. It is very difficult for large-scale promotion of employing extra-curricular teachers with financial background due to their qualifications, funding and management. Therefore, there is an urgent need to establish a high-level teaching staff capable of training compound financial professionals.

\section{Countermeasures and suggestions}

To optimize talents training programs combined with financial needs changing. Local colleges and universities should closely integrate the new demands of talents in the financial industry, take the cultivation of core competencies of applied talents as the goal, focus on professional construction, and actively promote the cooperation among universities, enterprises, schools and schools, strengthen the characteristics of running schools, and actively explore co-education People model, multi-coordinated interaction, in accordance with the new requirements of the financial occupation post group to determine the standards of professional training, accurate positioning of 
professional training objectives and specifications, and constantly optimize the training program. Efforts should be made to cultivate multi-disciplinary professionals who have solid knowledge of interdisciplinary subjects such as finance, statistics and computer, mastering core financial business skills such as financial asset pricing, financial risk management, and investment and financing.

To deepen the reform of curriculum system, teaching contents and assessing methods. Introduce the concept of "ability-based" and construct the curriculum system scientifically. In accordance with the industry and enterprise groups on the talent knowledge, ability and quality requirements, and strive to achieve professional chain and industrial chain, curriculum content and professional standards, teaching process and production process docking, the job requirements into professional ability to build with capacity of Oriented modular curriculum system. Establish a "combination of learning with" thinking, precise design of teaching content. Adhere to the application of capacity-building as the main line, employers to participate in the design of the course to participate in the teaching content, the theoretical teaching and practice teaching integration, and constantly improve the practical ability of students. According to the characteristics of the course, reform the examination examining method.

To promote practical teaching reform based on labor-education cooperation cultivation. Local colleges and universities should work together with financial institutions to achieve the teaching resources, financial data, results display platform, online sharing of discussions, the realization of a high degree of integration of production and education, joint training of compound talents. On the one hand, we should step up the building of a traditional off-campus internship practice base and sign practical cooperation agreements with financial institutions such as local commercial banks, insurance companies, securities companies and private placement funds to ensure that students can "go global" to internships in financial institutions ; On the other hand, we can deepen the reform of practical teaching content in accordance with the concept of "reforming enterprises into campus". The second classroom, innovative credits into professional training programs, through the organization of "post situational simulation training", "practice semester", "famous lecture hall", "outstanding alumni, business mentor into the classroom" and other links, as well as to encourage students to participate Disciplinary competitions held by financial institutions and various social practice activities to improve the efficiency of teaching, cultivate students 'abilities and thinking modes of solving practical problems and effectively improve the students' practical application ability. This will effectively solve the employer cannot find the right people, students cannot find the corresponding job dilemma.

To build a high quality teaching groups standing in industrial forefront. Local colleges and universities to train financial professionals, the focus is still on the construction of a high level of teaching staff. First of all, schools should provide competitive salaries and remunerations to attract more professional teachers, especially teachers who have a background in financial practice and computer science. Secondly, they should take effective measures to encourage teachers to participate in interdisciplinary training, Visiting study, in-service study degree, post training, instruct students to participate in various forms of academic competitions, both to encourage teachers to improve research capabilities, and voluntarily to enhance financial practice skills, and vigorously develop practical courses; the final financial The rapid development of the forefront of knowledge and products often only practitioners to master, should actively explore the external teacher system, some very technical and practical course can be taught by business mentor.

\section{Acknowledgment}

This thesis is founded by Shandong Province Human \& Social Science Program (17-ND-JJ-15), Shandong Province Natural Science Foundation Program (ZR2014GL010), National Spark Program (2013GA740012) and Shandong Spark Program (2012XH06033), hereby express acknowledgments to them. 


\section{References}

[1] Zhang Minfeng. New economic normal, financial science and technology and local colleges and universities financial professionals training and innovation [J]. Financial Theory and Teaching, 2017(6):26-29.

[2] Wang Bing. Promote wisdom and proceed by wind - on the application of artificial intelligence in finance [J]. China Financial Computing, 2017 (1): 27-30.

[3] Xing Yu. Reflections on Experimental Teaching of Financial Engineering in the Context of Artificial Intelligence [J]. Journal of Education Modernization, 2017(33): 138-140.

[4] Xing Guwei. Artificial Intelligence, A New Direction of Financial Digitization [J]. China Financial Computer, 2017(5): 59-63.

[5] Wu Jun, Chen Liang, Gao Yong. The Application of Foreign Artificial Intelligence in the Field of Financial Investment Consultants and Its Inspiration to China [J]. Finance and Economic Transactions, 2016 (6): 88-92.

[6] Yu XiaoJian, Peng YongYu. Application and Challenges of Artificial Intelligence in Financial Risk Management [J]. Southern Finance, 2017 (9): 70-74.

[7] Zhang Yifan. Artificial intelligence technology in the financial industry applications [J]. Electronic Engineering and Software Engineering, 2016 (23): 25-28. 